\title{
Giant reed (Arundo donax L.) harvesting system, an economic and technical evaluation
}

\author{
M. Bentini, ${ }^{1}$ R. Martelli ${ }^{1}$ \\ 'Department of Agricultural and FoodSciences, University of Bologna, Bologna, Italy
}

\begin{abstract}
The giant reed is a herbaceous energy crop that demonstrates a good adaptability for areas of central-northern Italy. However, its size and stem resistance to cutting pose problems for harvesting in relation both to the availability of suitable machinery and costs of the operation. A technical and economic evaluation has been conducted of a harvesting system based on an experimental machine, the biotriturator, developed by University of Bologna in collaboration with the Nobili Company (Bologna, Italy) and adapted to field operating conditions.

The harvesting system consists of cutting-shredding and baling in a single pass. The system was evaluated by performing a winter harvest when the crop was in quiescence and had a low moisture content.

The total harvesting costs were evaluated as $11.6 € \mathrm{Mg}^{-1}$ dry biomass. Given that the estimated area that can be covered by the harvesting system was 123 hectares per year the system represents an effective solution for not very large areas and is therefore suitable for the Italian environment where average farm sizes are slightly over seven hectares (ISTAT, 2011).
\end{abstract}

\section{Introduction}

Dedicated energy crops can play a key role in providing substantial amounts of lignocellulosic feedstocks required for the second-generation biofuel production chain as well as heat and electricity production (JRC EC, 2011). The main barrier to the diffusion of crops for bioenergy is cost competitiveness with fossil fuels. To create a reli-

Correspondence: Roberta Martelli, Dipartimento di Scienze e Tecnologie Agro-Alimentari, Università di Bologna, via G. Fanin 50, 40127 Bologna, Italy. Tel. +39.051.2096175 - Fax: +39.051.2096178

E-mail: roberta.martelli@unibo.it

Key words: cost analysis, giant reed (Arundo donax), harvesting system, herbaceous energy crops.

Copyright M. Bentini et al., 2013

Licensee PAGEPress, Italy

Journal of Agricultural Engineering 2013;XLIV(s2):e120

doi:10.4081/jae.2013.s2.e120

This article is distributed under the terms of the Creative Commons Attribution Noncommercial License (by-nc 3.0) which permits any noncommercial use, distribution, and reproduction in any medium, provided the original author(s) and source are credited. able supply chain it is necessary to achieve efficient and sustainable cultivation.

The perennial grass giant reed (Arundo donax L.) is considered as particularly promising for Mediterranean regions, because of high yields in lignocellulosic biomass, a good adaptability to these environments and its very low soil tillage, pesticide and fertilizer requirements (Lewandowski et al., 2003; Angelini et al., 2005, 2009)

The harvesting can be a critic al phase of giant reed cultivation mainly due to the lack of harvesting machines (Venturi and Bentini, 2005). As well as being very tall and having a high cutting resistance, Arundo is a rhizomatous grass that is not laid out in regular rows and is also sometimes partially lodged (Yitao et al., 2007). It is therefore necessary to design a specific machine or adapt machines developed for other crops.

The harvesting process requires mow-conditioning, raking and baling or loading of loose chopped biomass for delivery to the energy plant. Depending on the moisture content of the biomass a partial drying in the field may be necessary prior to baling or delivery (Trebbi, 1993). The giant reed can also be harvested in winter, with partial drying of the plants in the field improving the characteristics of the biomass in terms of specific energy and reducing the storage and handling costs.

In this paper, a prototype for the cutting and chopping of giant reed has been evaluated. A technical economic analysis has been conducted of a cutting-shredding-baling system that can harvest the crop in a single operation.

\section{Material and methods}

Harvesting trials were done on a 7-year-old giant reed crop with a 1 $\mathrm{x} 1 \mathrm{~m}$ planting layout obtained from rhizomes of an ecotype selected at the University of Catania. The crop was harvested at the end of February when plants were in winter quiescence and had a low moisture content. A prototype biotriturator RM $280 \mathrm{BIO}$ was used, which combines cutting, shredding and crop windrowing. The equipment was developed by the Agricultural and Food Sciences Department of the University of Bologna, in collaboration with Nobili S.r.l. (Bologna, Italy). The machine was composed of a cutting shredding chamber surmounted by a dividing conveyor, constituted by a frame to channel the plants into the shredding chamber. The shredding system consisted of a horizontal rotor with 64 half Y-shaped fl ail blades, the eight rows of flails were staggered. A double auger conveyor situated in the rear of the shredding chamber allowed the biomass to be raked. The biotriturator was front-mounted with a three point hitch on a 4-wheeldrive tractor CNH T6090 (147 kW) (CNH Corporation), with a Kuhn VB2160 round baler (Kuhn S.r.l., Italy) rear-mounted on the same tractor. The baler was a variable chamber that wrapped the bales in nets (Figure 1,2). 
Table 1. Implement and tractor cost data

\begin{tabular}{lcccc} 
& & Tractor & Biotriturator & Baler \\
Purchase price & $€$ & 84000 & 7500 & 24000 \\
Estimated life & $\mathrm{h}$ & 8000 & 1000 & 1000 \\
\hline Annual use & $\mathrm{h}$ & 800 & 200 & 200 \\
Remaining value & $\mathrm{C} 1$ & 0.976 & 0.756 & 0.852 \\
\hline coefficient & $\mathrm{C} 2$ & 0.119 & 0.067 & 0.101 \\
& $\mathrm{C} 3$ & 0.0019 & & \\
Insurance and housing & $\%$ & 1 & 1 & 1 \\
\hline RF1 & & 0.019 & 0.44 & 0.43 \\
RF2 & & 1.3 & 2.0 & 1.8 \\
\hline
\end{tabular}

Table 2. Crop characteristics

\begin{tabular}{lcc} 
Plant age & years & 7 \\
Average density & shoots $\mathrm{m}^{-2}$ & 15 \\
\hline Stem length m & 3.7 & \\
Moisture at harvest (wet) & $\%$ & 41 \\
\hline Average yield (dry) & Mg ha- $^{-1}$ & 20.1 \\
\hline
\end{tabular}

Table 3. Operative characteristics of harvesting systems

\begin{tabular}{lcc} 
Field speed & $\mathrm{km} \mathrm{h}^{-1}$ & 4.0 \\
Machine working width & $\mathrm{m}$ & 2.80 \\
\hline Field efficiency & & 0.55 \\
Effective field capacity* & $\mathrm{Mg} \mathrm{h}^{-1}$ & 12.5 \\
\hline Area covered per year & ha & 123 \\
\hline
\end{tabular}

*Referred to dry biomass

Bales were measured and then weighed directly in the field suspended by belts on an electronic dynamometer (Figure 3). The bulk density and moisture content on a wet basis were determined.

The effective field capacity of the machine was evaluated considering the working times measured during the field trials on the basis of Standard ASAE EP496.3.

The total machinery costs are calculated including charges for ownership and operation and are based on buying a new machine and using a tractor for 10 years and implements for 5 years.

The ownership includes depreciation, interest on the investment, insurance and housing of the machine (Standard ASAE S495.1). The purchase price is based on the manufacturer's list price minus a percentage discount indicated by the dealers interviewed (20\% for a tractor and $15 \%$ for implements). Other variables used in calculating costs are shown in Table 1.

Annual use was assumed as $200 \mathrm{~h}$ for implements and $800 \mathrm{~h}$ for tractors. The remaining value was calculated on the basis of Standard ASAE D497.7. The other ownership costs, insurance and housing were calculated as a percentage of the purchase price. For the interest charged on borrowing the money a rate of $5 \%$ on the average investment was applied.

Labour costs are based on 14.50 euros per hour labour charge, including taxes and social security contributions. Fuel costs are based on diesel fuel priced at 0.93 euros per litre. The total repair and maintenance charges take into account the amount of use and were calculated on the basis of Standard ASAE EP496.3. For the tractor, the repair and maintenance indices relative to the specific Italian situation were used (Calcante et al., 2011).

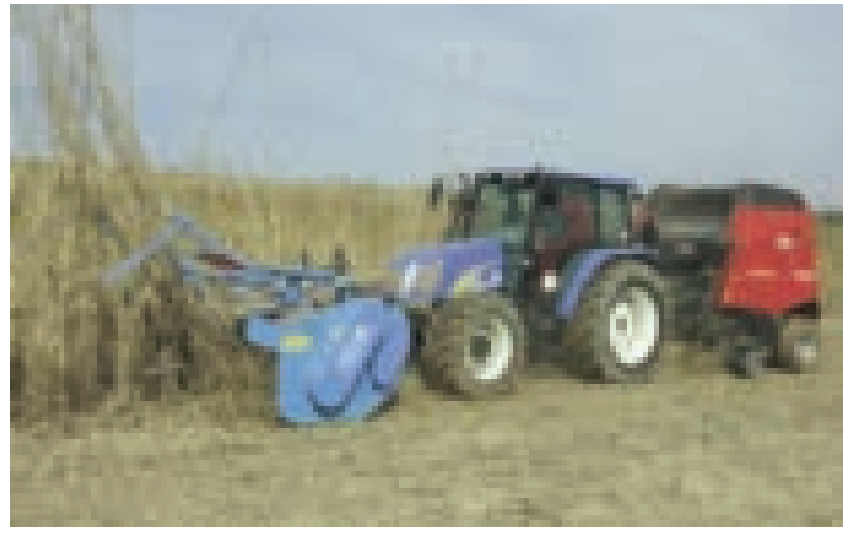

Figure 1. Baler during ejection phase

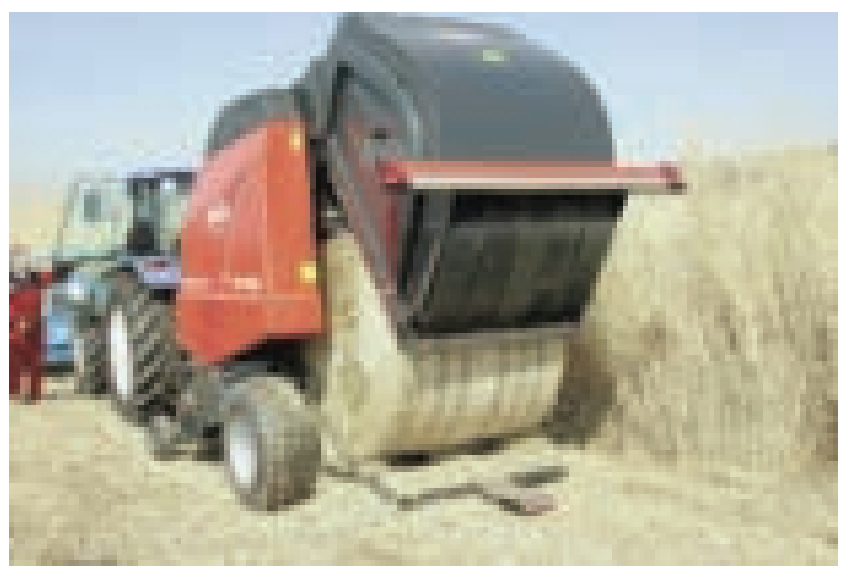

Figure 2. Harvesting system

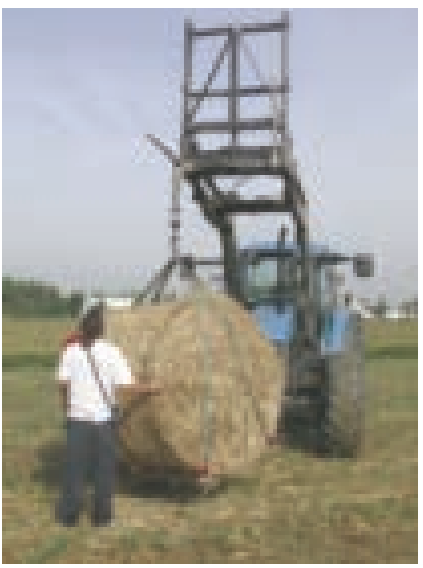

Figure 3. Bale weighing 


\section{Results}

Table 2 reports average values of the crop characteristics measured at harvesting. The average stem height was $3.7 \mathrm{~m}$ with values in the range 2.4-4.4 m, at a density of 15 shoots $\mathrm{m}-2$. The yield represents the amount of biomass collected from the field, not the total amount of above-ground biomass.

For the evaluation of costs and machine performance reference was made to the data obtained in the field trial, which were comparable with average values obtained in other studies done in areas of central-northern Italy (Angelini et al., 2005, 2009).

The field speed was $4.0 \mathrm{~km} \mathrm{~h}^{-1}$, with a field efficiency of 0.55 limited by the wrapping and ejecting times of the round baler. The effective field capacity was $0.62 \mathrm{ha} \mathrm{h}^{-1}$ that, on the basis of the hypothesized annual use, allows an area of 123 hectares per year to be covered (Table 3 ).

The average volume of the bales was $2.4 \mathrm{~m} 3$ (1.6 m diameter by 1.2 m wide) with a mass of $407 \mathrm{~kg}$, moisture content on a wet basis of $41 \%$ and density $170 \mathrm{~kg} \mathrm{~m}-3$.

The cost of the harvesting system amounted to $233.3 €$ ha $^{-1}$, due to $78.9 € \mathrm{ha}^{-1}$ for the tractor (including fuel and oil costs), $130.9 € \mathrm{ha}^{-1}$ equipment overheads and $23.5 € \mathrm{ha}^{-1}$ labour cost for the tractor driver. The total harvesting cost per unit of dry biomass was $11.6 € \mathrm{Mg}^{-1}$.

The cost of net for the round baler was 0.81 euros for bale and was included in the total, while costs to transport the biomass from field to plant and for storage were not included.

The majority of implement costs were for interest and depreciation, corresponding to around $62 \%$ of the total cost for the baler and biotriturator and $74 \%$ for the tractor excluding the labour cost.

\section{Discussion}

The average speed of the harvesting system is $4.0 \mathrm{~km} \mathrm{~h}^{-1}$ and is always lower than $4.5 \mathrm{~km} \mathrm{~h}^{-1}$, due both to the high cutting resistance of the culms of giant reed and the irregular crop distribution in the field, which over the years tends to invade the inter-rows.

The working capacity of the system is also limited by the baling phase, which has low field efficiency because of the need to stop the machine during the wrapping and ejecting.

Comparison of the biomass harvesting costs with other studies is difficult because of differences in assumption and methods. In addition, while analyses have been done on the harvesting costs of biomass crops such as sorghum and switchgrass (Cundiff and Marsh, 1996; Thorsell et al., 2004; Sokhansanj et al., 2009; Lychnaras and Schneider, 2011), to our knowledge no studies are available on the costs of the mechanised harvesting of Arundo.

\section{Conclusions}

The prototype is able to perform properly the harvesting of giant reed even if the crop is not laid out in regular rows but the high shear strength of the culms limits the machine speed. The machine can also used on other energy crops such as sorghum and switchgrass.

This system anyway showed reasonable harvesting costs for not very large areas (around $200 \mathrm{ha}$ ) and is therefore suitable for situations like that in Italy, where average farm sizes are slightly over 7 hectares.

In the future, with the expected diffusion of dedicated energy crops with winter harvest, the development of a combine is advisable that both shreds and bales without the feedstock coming into contact with the ground to reduce contamination by inorganic material, and consequently lower the ash content.

\section{References}

Angelini L., Ceccarini L., Bonari E. Biomass yield and energy balance of giant reed (Arundo donax L.) cropped in Central Italy as related to different management practices. European Journal of Agronomy 2005;22:375-89.

Angelini L.G., Ceccarini L., Nassi o Di Nasso N., Bonari E. Comparison of Arundo donax L. and Miscanthus $\mathrm{x}$ giganteus in a long-term field experiment in Central Italy: Analysis of productive characteristics and energy balance. Biomass Bioenergy 2009;33:635-43.

ASAE. Uniform Terminology for Agricultural Machinery Management. St. Joseph (MI): American Society of Agricultural and Biological Engineers. 2005 Nov. Standard ASAE S495.1.

ASAE. Agricultural Machinery Management. St. Joseph (MI): American Society of Agricultural and Biological Engineers. 2007 Feb. Standard ASAE EP496.3.

ASAE. Agricultural Machinery Management Data. St. Joseph (MI): American Society of Agricultural and Biological Engineers. 2011 March. Standard ASAE D497.7.

Calcante A., Mazzetto F., Fontanini L. Verifica dei parametri del modello per il calcolo dei costi di manutenzione e riparazione di trattori $4 \mathrm{rm}$ in pianura padana: primi risultati. Proceedings of the Conference: Gestione e Controllo dei Sistemi Agrari e Forestali, 2011 Sept 22-24, Belgirate, Verbania, Italy.

Cundiff J.S., Marsh L.S. Harvest and storage costs for bales of switchgrass in the southeastern United States. Bioresour. Technol. 1996;56:95-101.

JRC - European Commission 2011. Technology Map of the European Strategic Energy Technology Plan (SET-Plan) Technology Descriptions. Joint Research Centre - European Commission, Luxembourg, EU.

Lewandowski I., Scurlock J.M.O., Lindvall E., Christou M. The development and current status of perennial rhizomatous grasses as energy crops in the US and Europe. Biomass Bioenergy 2003;25:335-61.

Lychnaras V., Schneider U.A. Multi-farm economic analysis of perennial energy crops in Central Greece, taking into account the CAP reform. Biomass Bioenergy 2011;35:700-15.

Sokhansanj S., Mani S., Turhollow A., et al. Large scale production, harvest and logistics of switchgrass (Panicum virgatum L.)-current technology and envisioning a mature technology. Biofuels, Bioprod. Bioref. 2009;3:124-41.

National Institute of Statistics (ISTAT); 2011. VI Censimento generale dell'agricoltura. Available from: http://censimentoagricoltura.istat.it/fileadmin/template/main/res/c omunicato-censimento-agricoltura.pdf Accessed: May 2013.

Thorsell S,. Epplin F.M., Huhnke R.L., Taliaferro C.M. Economics of a coordinated biorefinery feedstock harvest system: lignocellulosic biomass harvest cost. Biomass Bioenergy 2004;27:327-37.

Trebbi G. Power-production options from biomass: The vision of a southern European utility. Bioresour. Technol. 1993;46:23-9.

Venturi P., Bentini M. La logistica delle biomasse: tecnologie di raccolta e stoccaggio. Agroindustria 2005;1:55-60.

Yitao L., Qingxi L., Boping T., et al. Experimental research on the mechanical physical parameters of bottom stalk of the Arundo donax L. in harvesting period. Transactions of the Chinese Society of Agricultural Engineering 2007;23:124-9. 